\title{
Bovine digital dermatitis in the Brazilian Amazon biome and topical treatment with Copaifera reticulata oil $^{1}$
}

\author{
Henrique A. Bomjardim²* (D), Mariana C. Oliveira ${ }^{3}$ (D) Marilene F. Brito $^{3}$ (D), \\ Carlos M.C. Oliveira ${ }^{4}$ (D), Bruno M. Monteiro ${ }^{5}$ (D), Natalia S.S. Silveira ${ }^{4}$ (D) \\ and José D. Barbosa ${ }^{4}$
}

\begin{abstract}
Bomjardim H.A., Oliveira M.C., Brito M.F., Oliveira C.M.C., Monteiro B.M., Silveira N.S.S. \& Barbosa J.D. 2020. Bovine digital dermatitis in the Brazilian Amazon biome and topic treatment with Copaifera reticulata oil. Pesquisa Veterinária Brasileira 40(11):842-851. Graduate Program in Animal Science, Instituto de Medicina Veterinária, Campus de Castanhal, Universidade Federal do Pará, Rodovia BR-316 Km 61, Castanhal, PA 68741-740, Brazil. E-mail: henriquebomjardim@unifesspa.edu.br

Bovine Digital Dermatitis (BDD) was studied in crossbred dairy cows grazing in Rondon do Pará, in the state of Pará, as well as in Açailândia and Cidelândia, in the state of Maranhão, Brazilian Amazon biome. The digits inspection from the dairy cows during milking was performed in ten farms comprising four visits (August and November 2016; April and July 2017). The cows were kept all year in pastures, and were mechanically milked on concrete floors and the animals were protected against the rains in eight farms, maintaining a daily cleaning, however, it could not be found a concrete floor in pre- or post-milking to ensure milking parlor on three farms. Manual milking on no concrete floors was performed in two farms. No preventive measures against hoof lesions were adopted. The BDD prevalence was $1.3 \%(22 / 1664)$, and no statistical difference among rainy or no rainy season was obtained $(p=0.72)$. The BDD lesions were classified according to "M system" ( $\mathrm{M} 0=$ no lesion, $\mathrm{M} 1=$ active ulceration $<2 \mathrm{~cm}, \mathrm{M} 2=$ active ulceration $>2 \mathrm{~cm}, \mathrm{M} 3=$ healing stage, $\mathrm{M} 4=$ chronic stage, M4.1 = M4 with active ulceration). Regarding the 22 BDD lesions observed, 22.7\% (5/22) were M1 stage, 36.4\% (8/22) M2, 22.7\% (5/22) M3, 13.6\% (3/22) M4 and 4.5 (1/22) M4.1. Hypertrophic hairs at the edges of the lesions caused by fly larvae of genus Cochliomyia spp. as well as alterations on the hoof were also observed. Topical treatment was performed in six BDD lesions with a raw extract from trees of the genus Copaifera reticulata (Copaiba oil) and compared with the treatment of salicylic acid paste in five BDD lesions. The lesions were protected with a bandage for seven days and followed weekly until recovery. The complete therapeutic responses were $83.4 \%(5 / 6)$ and $75 \%(3 / 4)$, respectively, with an average time of seven weeks. The BDD in the Amazon biome occurs in low prevalence, not seasonal, and presents macro and microscopic features similar to BDD lesions from dairy cattle kept in free-stall housing. The treatment with copaiba oil showed similar results to the treatment of salicylic acid paste and can be used in control measures to BDD in the Amazon biome.
\end{abstract}

INDEX TERMS: Bovine digital dermatitis, Amazon region, Brazil, topical treatment, Copaifera reticulata, copaiba oil, Mortellaro's disease, grazing system.

\footnotetext{
${ }^{1}$ Received on June 1, 2020.

Accepted for publication on June 16, 2020.

${ }^{2}$ Instituto de Estudos do Trópico Úmido (IETU), Universidade Federal do Sul e Sudeste do Pará (Unifesspa), Rua Alberto Santos Dumond s/n, Bairro Jardim Universitário, Xinguara, PA 68557-335, Brazil. *Corresponding author: henriquebomjardim@unifesspa.edu.br

${ }^{3}$ Departamento de Epidemiologia e Saúde Pública, Instituto de Veterinária (IV), Universidade Federal Rural do Rio de Janeiro (UFRRJ), BR-465 Km 7, Seropédica, RJ 23890-000, Brazil.

${ }^{4}$ Faculdade de Medicina Veterinária, Instituto de Medicina Veterinária, Universidade Federal do Pará (UFPA), Campus de Castanhal, Rodovia BR316 Km 61, Castanhal, PA 68741-740, Brazil.

${ }^{5}$ Universidade Federal Rural da Amazônia (UFRA), Campus Paragominas, Rodovia PA-256, Paragominas, PA 68627-451, Brazil.
}

RESUMO.- [Dermatite digital bovina no bioma amazônico brasileiro e tratamento tópico com óleo de Copaifera reticulata.] A dermatite digital bovina (DDB) foi estudada em vacas mestiças leiteiras nos municípios de Rondon do Pará no Pará, Açailândia e Cidelândia no Maranhão, bioma amazônico brasileiro. Para tanto, foram realizadas quatro visitas a 10 propriedades, nos meses de agosto e novembro em 2016 e abril e julho em 2017, e realizada a inspeção dos dígitos de 1.664 vacas em lactação durante a ordenha. Nestas propriedades as vacas eram criadas a pasto durante todo o ano e ordenhadas mecanicamente em oito propriedades. As quais, 
as salas de ordenha tinham piso concretado, com proteção contra as chuvas e era realizada a limpeza diariamente. No entanto, em três dessas propriedades, as salas de pré ou pós ordenha tinham piso não concretado e em duas, a ordenha era manual em piso de chão batido. Em todas elas não havia medidas profiláticas para afecções podais. A prevalência de DDB foi de $1,3 \%(22 / 1.664)$ e não se obteve diferença estatística entre os períodos chuvoso e não chuvoso $(\mathrm{P}=0,72)$. As lesões observadas foram classificadas de acordo com o sistema $\mathrm{M}$ (M0-sem lesão; M1-lesão ulcerada <2cm; M2-lesão ulcerada >2cm; M3-lesão em cicatrização; M4-lesão crônica; M4.1- M4 com área ulcerada). De 22 lesões observadas, 22,7\% (5/22) apresentavam-se em estágio M1, 36,4\% (8/22) em M2, 22,7\% (5/22) em M3, 13,6\% (3/22) em M4 e 4,5\% (1/22) em M4.1. Pelos hipertrofiados nos bordos das lesões, larvas de moscas do gênero Cochliomyia spp. e alterações no tecido córneo também foram observados. Nas lesões de 11 bovinos, em seis, foi realizado o tratamento tópico com extrato bruto de Copaifera reticulata (óleo de copaíba) e em cinco, com a pasta de ácido salicílico a $660 \mathrm{mg} / \mathrm{g}$ e ambos os tratamentos foram protegidos com bandagem por sete dias. Após, as lesões foram acompanhadas semanalmente até a cura e obteve-se um índice de $83,4 \%$ (5/6) e 75\% (3/4) de cura com esses tratamentos, respectivamente, com uma média de 7 semanas. Conclui-se que no bioma amazônico a DDB ocorre em baixa prevalência, não sazonal e com características macroscópicas semelhantes às lesões de vacas leiteiras criadas em sistema free stall. 0 tratamento com o óleo da copaíba apresentou resultados semelhante ao ácido salicílico e pode ser uma alternativa como medida de controle da DDB no bioma amazônico.

TERMOS DE INDEXAÇÃO: Dermatite digital bovina, região Amazônica, Brasil, tratamento tópico, Copaifera reticulata, óleo de copaíba, doença de Mortellaro, criação a pasto.

\section{INTRODUCTION}

Bovine digital dermatitis (BDD) is a contagious inflammatory lesion of the skin of bovine digits (Cheli \& Mortellaro 1974). It has a multifactorial etiology with the interaction between environment, host, and bacterial agents, especially spirochetes of the genus Treponema sp. (Blowey \& Sharp 1988, RodríguezLainz et al. 1996, Scholey et al. 2010, Krull et al. 2014). It is a disease that may be considered endemic when dairy cows are kept in free-stall stables (Wilson-Welder et al. 2015) and being of low prevalence in beef cattle and crossbred dairy cows kept in a pasture (Wells et al. 1999, Brown et al. 2000, Silveira et al. 2009, 2018, Sullivan et al. 2013).

This disease was firstly described in Italy in 1974, and in the following years also in other European countries and North America, however, nowadays, the BDD is a worldwide disease (Blowey \& Sharp 1988, Murray et al. 1996, Rodríguez-Lainz et al. 1999, Manske et al. 2002a, Sogstad et al. 2005). Among foot disorders, it stands out as the primary infectious disease that affects cloven-hoofed animals (Cramer et al. 2008). In Brazil, BDD has already been reported in dairy cattle in the states of Minas Gerais, Rio Grande do Sul, Goiás, Maranhão, and Pará (Molina et al. 1999, Cruz et al. 2001, Silva et al. 2001, Machado et al. 2008, Silveira et al. 2009, Moreira et al. 2018) and also in beef cattle in the states of Rio Grande do Sul and Pará (Cruz et al. 2005, Silveira et al. 2018).
Thus, the BDD injuries regarding the acute phase are painful and cause the lameness, notwithstanding the evidence, the main clinical consequence has severe implications for animal welfare (Sullivan et al. 2013). Therefore, economic losses related to the productive sector are associated with less milk production, low reproductive performance and treatment expenses (Barkema et al. 1994, Argáez-Rodríguez et al. 1997, Somers et al. 2005, Losinger 2006, Relun et al. 2013a).

Commonly, the control of BDD has been carried out with the topical and systemic application of antibiotics. Among these, oxytetracycline is often used with significant results (Manske et al. 2002b). On the other hand, solutions containing formaldehyde, copper, or zinc sulfate in footbaths, have also been used, but fell into disuse (Laven \& Logue 2006). However, other alternatives have been tested owing to bacterial resistance related to overuse or inappropriate use of antibiotic therapy, as well as the presence of residues in milk or meat, and the high costs and toxicity in the use of formaldehyde or copper sulfate (Moore et al. 2001, Holzhauer et al. 2011, Evans et al. 2016, Yamamoto et al. 2018). As alternative treatments, there are raising incentives to invest in non-antibiotic products, i.e., having good efficacy, low cost, and low toxicity, which do not generate residues in the milk and are relatively easy to use.

Among the alternatives for using antibiotics, the salicylic acid (2-hydroxybenzoic), protected by bandages, has been shown efficacy similar to the treatment with oxytetracycline in dairy cows (Schultz \& Capion 2013). This salicylic acid has antimicrobial, keratinolytic, and keratoplastic effects; i.e., in addition to "fighting" bacteria, it can dissolve the superficial layer of the epidermis and act in deeper layers and promote tissue repair (Lodén et al. 1995, Monte et al. 2014). Salicylic acid, seeing that it is a non-antibiotic product, and shall be allowed a 24-hour grace period for meat and milk, may present positive results for the treatment of BDD (Schultz \& Capion 2013).

In Brazil, a natural substance extracted from the trunk of trees of the genus Copaifera L., commonly known as copaiba oil, is used in traditional folk medicine to treat various diseases in humans and animals (Pieri et al. 2009). In the Amazon region, this oil is well known and also available at low cost in open markets and markets in general. Copaiba oil is a substance rich in diterpenic acids and sesquiterpene hydrocarbons that have, among other properties, antimicrobial activities, anti-inflammatory effects, analgesic, and healing actions (Cascon \& Gilbert 2000, Carvalho et al. 2005, Pacheco et al. 2006, Veiga Júnior et al. 2007, Santos et al. 2008, Barbosa et al. 2019). This plant may be used due their properties, and it could be a useful and ecologically sustainable alternative in treating BDD in the Brazilian Amazon region.

In this region, where animals are allowed to graze throughout the year, and therefore there is a dairy cattle breed predilections, seeing that these animals are more resistant to high temperatures and humidity. On the other hand, the BDD's epidemiological situation is not well studied, and alternative treatments for using of antibiotics should be proposed. Therefore, the objective of this study was aimed to investigate the BDD in crossbred dairy cows reared under pasture in the Brazilian Amazon biome, as well as testing the topical treatment for skin lesions with the crude extract of Copaifera reticulata and comparing the data with the treatment with salicylic acid paste. 


\section{MATERIALS AND METHODS}

Study area and period. The BDD was evaluated in crossbred dairy cows in 10 properties located in the municipalities of Rondon do Pará/PA, Açailândia/MA and Cidelândia/MA, in the Brazilian Amazon biome. The climate of this region is related to the category of super humid equatorial, type Am, according to the Köppen classification, also being at the limit of transition to type Aw. It has average annual temperatures of $26^{\circ} \mathrm{C}$ (maximum of $32^{\circ} \mathrm{C}$ and minimum of $22^{\circ} \mathrm{C}$ ). The relative humidity is high, between climate oscillations in the rainy season (from November to May) and the dry season (from June to October), from 100 to $52 \%$, and an average of 78\%. The index of annual rainfall has an average of 2,000mm (Rondon do Pará 2018). Four visits were made in 2016 and 2017 - the first visit was in August 2016, the second one in November 2016, the third in April 2017, and the forth in July 2017.

Previously, and when visiting the properties, the cumulative rainfall indexes of the region were obtained from the database of the "Instituto Nacional de Meteorologia" (INMET) of the meteorological station in the municipality of Rondon do Pará, from January 2016 to July 2017 (INMET 2018), in order to assess possible seasonality in the occurrence of the disease.

The study was carried out according to the ethical principles of animal experimentation recommended by the "Colégio Brasileiro de Experimentação Animal" (COBEA).

Studied farms. The farms were selected owing to their prior knowledge regarding foot disorders as well as the producers' acceptance to participate in the study. The dairy cows were kept on pasture, in which the vegetation consists of Urochloa brizantha (synonym Brachiaria) (about 95\%) and grasses of the genus Panicum spp. cv Mombaça and being added commercial mineral supplementation. Supplementation with cornmeal concentrate and soybean meal, corn silage, or sugar cane was offered to the animals in $50 \%(5 / 10)$ of the properties, mainly in the dry period. In $80 \%$ $(8 / 10)$ of the properties, milking was mechanized and carried out in rooms with concrete floors and the animals were protected against rain, including pre-and/or post-milking rooms on concrete floors or beaten floors. In $20 \%$ (2/10) of the properties, milking was manual and carried out in a place with a beaten floor. In the properties in which mechanical milking was carried out, and the milking rooms was cleaned daily and at the end of each milking session. This cleaning could be done by scraping the organic matter and washing with water. All properties did not adopt measures to prevent foot infections or control the animals that entry into the herd (Table 1).

Animals. The crossbreeding had herds that were composed from the Holstein breed's crosses between the Zebu breeds (Gir, Guzerá, Tabapuã, and Nelore) in different blood grades, from three to 12 years of age and at different stages of the lactation period.

Diagnosis. The BDD diagnosis was performed during the milking of dairy cows by inspecting all bovine distal limbs with a flashlight. When the organic matter adhered to the distal limbs, they were superficially scraped (manual milking) or cleaned with water jets (mechanical milking).

The bovine distal limbs of 1,664 dairy cows were inspected. Concerning the four visits in order to test all dairy cows, it was not possible to identify each animal, and some bovine distal limbs were inspected more than once. Indeed, some cows in lactation moved to the dry cow group after the first visit, and others belonging to the dry cow group moved to the lactating cow group since there were cows in different third lactation.

At the end of milking, it was performed the scores of claudication symptoms of dairy cows identified with BDD, on a scale from 0 (without claudication) to 5 (severe claudication), according to Flower \& Weary (2006). Afterward, physical restraint was performed with ropes and kept in the lateral position for cleaning, inspection, and treatment. In dairy cows highly agitated, $2 \%$ xylazine at a dose of $0.1 \mathrm{mg} / \mathrm{kg}$ body weight was previously administered intramuscularly. The distal extremities were then washed with water, and the lesions measured in centimeters in the vertical and horizontal directions. The anatomical location and macroscopic characteristics were described, as well as the photographic record.

Classification. The lesions were classified into four stages, according to their macro and microscopic characteristics, such as, M1 (first stage of ulcer, $<2 \mathrm{~cm}$ in diameter), M2 (stage of painful ulcer, $>2 \mathrm{~cm}$ ), M3 (healing stage, covered in a crust), M4 (chronic stage with hyperkeratotic surface), M4.1 (stage M4 with ulcerated area), according to the score of Döpfer et al. (1997) and Berry et al. (2012).

Table 1. Characteristics of the 10 properties studied regarding the size of the dairy cows lots, supplemented with concentrate and corn or sugarcane silage, manual or mechanical milking and the type of flooring material of the milking pens in the Brazilian biome

\begin{tabular}{|c|c|c|c|c|c|c|c|c|c|c|}
\hline \multirow[b]{2}{*}{ Municipality } & \multirow[b]{2}{*}{ Property } & \multirow{2}{*}{$\begin{array}{l}\text { Dairy } \\
\text { cows* }\end{array}$} & \multicolumn{3}{|c|}{ Concentrate } & \multirow{2}{*}{$\begin{array}{c}\text { Silage** } \\
\text { kg/animal }\end{array}$} & \multirow[b]{2}{*}{ Milking*** } & \multicolumn{3}{|c|}{ Concrete flooring } \\
\hline & & & $\mathrm{kg} / \mathrm{animal} /$ day & Offer period & $\begin{array}{l}\text { Animals } \\
\text { quantity }\end{array}$ & & & Pre-milking & Milking & Post-milking \\
\hline \multirow[t]{4}{*}{ Rondon do Pará /PA } & I & 70 & 3 & Dry & All & - & ME & $\mathrm{X}$ & $X$ & - \\
\hline & III & 50 & 4.5 & Dry and rainy & 20 cows & $\mathrm{X}$ & ME & $\mathrm{X}$ & $\mathrm{X}$ & - \\
\hline & IV & 20 & 2 & Dry & All & - & ME & - & $\mathrm{X}$ & - \\
\hline & $\mathrm{V}$ & 25 & - & - & - & - & ME & - & $\mathrm{X}$ & - \\
\hline \multirow[t]{3}{*}{ Açailândia/MA } & VII & 60 & - & - & - & - & MAM & - & - & - \\
\hline & VIII & 40 & - & - & - & - & MAM & - & - & - \\
\hline & IX & 35 & 6 & Dry and rainy & 14 cows & - & $\mathrm{ME}$ & $\mathrm{X}$ & $\mathrm{X}$ & - \\
\hline
\end{tabular}

* Average dairy cows between the four visits made, ${ }^{* *}$ about 10 to $15 \mathrm{~kg} /$ animal/day of corn silage was offered; on property II, cows received about 25 to $30 \mathrm{~kg} /$ animal $/$ day of corn or sugarcane, ${ }^{* * *} \mathrm{ME}=$ mechanical milking, $\mathrm{MAM}=$ manual milking; $\mathrm{PA}=$ Pará, MA = Maranhão. 
Treatment. Topical treatment was tested, with approximately $7 \mathrm{ml}$ of crude extract of Copaifera reticulata, in six BDD lesions of six cattle. After the biopsy, histopathological study and molecular biology were performed, described by Bomjardim et al. (2020). The extract used was obtained by drilling the tree trunk in August 2016 in Rondon do Pará. The species was determined by the "Empresa Brasileira de Pesquisa Agropecuária” (Embrapa) Amazônia Oriental. For comparing the two groups, topical treatment with $10 \mathrm{~g}$ of a commercial paste based on $660 \mathrm{mg} / \mathrm{g}$ salicylic acid (Novaderma ${ }^{\circledR}$, WDT, Garbsen, Germany) was also carried out on five BDD lesions of five cattle. Both products were applied with a bandage composed of gauze, orthopedic cotton, crepon bandage, and adhesive tape. The bandage was removed after seven days, and a macroscopic description of the lesions was performed. All treated cattle were followed up, and the lesions were described weekly until healing.

Statistical analysis. The binomial variables were presented in percentage (\%) for the frequency of occurrence. The comparison between the variables according to the visits (1,2,3, and 4) was carried out by analysis of variance (ANOVA), using the GLASMIX procedure of SAS ${ }^{\circledR}$ version 9.3 (SAS/STAT, SAS Institute Inc., Cary, NC, USA).

The statistical models were based on the linear effects in classification method regarding variable visit and farms (I to X). The binary response variables consisted of the occurrences of BDD and lesion stages (dist = binomial).

Correlation analyzes were performed using the SAS CORR RANK procedure. The continuous response variables were submitted to the normality of residues and homogeneity of variances tests through the Guided Data Analysis Solutions of SAS. The variables that did not meet the statistical assumptions were converted into it. The tables were made using Microsoft Excel version 2010 for Windows 7.0. Significant difference was considered when $p \leq 0.05$.

\section{RESULTS}

\section{Prevalence}

According to the four visits in 10 properties, the BDD was diagnosed in $90 \%$ (9/10) of the properties, being detected in, at least, one of the four visits made, with a prevalence of $1.3 \%$ $(22 / 1,664)$. Between visits, there was no significant difference in the occurrence of BDD ( $p=0.72)$ (Table 2) and no statistical correlations were observed between the occurrence of BDD and the rainfall index ( $\mathrm{r}=0.02, p=0.38$ ) (Fig.1).

\section{Clinical characteristics}

The BDD was observed mainly in the plantar region and affected the commissure of the inter digital space and/or in the coronary bands, but also in the palmar region, as well as in the medial portion of the quartile and cranial of the commissure of inter digital space. By evaluating these animals, the claudication was a discrete clinical sign and scores ranged from 1 to 2 , including the absent one (Table 3 ).

The lesions were diagnosed in the first stage of ulcer (M1 and M2), healing stage (M3), chronic stage (M4), and chronic stage with an area of ulceration (M4.1). Regarding the forms of ulcers, the lesion sizes ranged from 1.0 to $5.5 \mathrm{~cm}$, being spherical to oval in shape, with concave, alopecic, moist, reddish surfaces, as well as with a granular surface, being painful to touch the high edges. The healing lesion sizes ranged from 0.3 to $4.5 \mathrm{~cm}$ and covered with grayish crusty material. In three

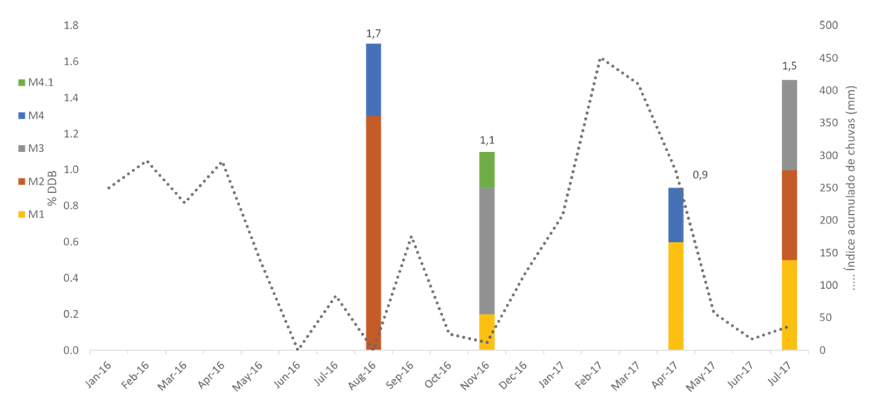

Fig.1. Graphical representation of the index of rainfall accumulation from January 2016 to July 2017 and the prevalence of bovine digital dermatitis (BDD) and scores distributed through the four visits (1st visit: Aug./16, 2nd visit = Nov./16, 3rd visit: Apr./17, 4th visit: Jul./17) that were conducted within 10 properties in Rondon do Pará/PA, Açailândia/MA and Cidelândia/MA in the Brazilian Amazon biome.

Table 2. Quantities of dairy cows inspected by property and number of animals with bovine digital dermatitis (BDD), as well as the percentage in the four visits carried out from August 2016 to July 2017

\begin{tabular}{|c|c|c|c|c|c|c|c|c|c|c|c|c|}
\hline \multirow{4}{*}{ Property } & \multicolumn{12}{|c|}{ Visits } \\
\hline & \multirow{2}{*}{\multicolumn{3}{|c|}{$\begin{array}{c}\text { 1st - Aug/16 } \\
\text { Animals }\end{array}$}} & \multirow{2}{*}{\multicolumn{3}{|c|}{$\begin{array}{c}\text { 2nd - Nov/16 } \\
\text { Animals }\end{array}$}} & \multirow{2}{*}{\multicolumn{3}{|c|}{$\begin{array}{c}\text { 3rd - Apr } / 17 \\
\text { Animals }\end{array}$}} & \multirow{2}{*}{\multicolumn{3}{|c|}{$\begin{array}{c}\text { 4th - Jul/17 } \\
\text { Animals }\end{array}$}} \\
\hline & & & & & & & & & & & & \\
\hline & $\mathrm{n}$ & BDD & $\%$ & $\mathrm{n}$ & BDD & $\%$ & $\mathrm{n}$ & BDD & $\%$ & $\mathrm{n}$ & BDD & $\%$ \\
\hline I & 81 & 2 & 2.5 & 73 & - & - & 55 & 1 & 1.8 & 61 & - & - \\
\hline II & 78 & 1 & 1.3 & 74 & - & - & 41 & - & - & 30 & 1 & 3.3 \\
\hline III & 52 & 1 & 1.9 & 53 & 1 & 1.9 & 42 & - & - & 61 & 1 & 1.6 \\
\hline IV & 22 & - & - & 19 & 1 & 5.3 & 10 & - & - & 23 & - & - \\
\hline V & 27 & 1 & 3.7 & 29 & 2 & 6.9 & 22 & 1 & 4.6 & 19 & 1 & 5.3 \\
\hline VI & 14 & 1 & 7.1 & 15 & - & - & 12 & - & - & 18 & - & - \\
\hline VII & 69 & 1 & 1.5 & 69 & - & - & 43 & - & - & 50 & - & - \\
\hline VIII & 49 & 1 & 2.0 & 31 & 1 & 3.2 & 33 & - & - & $*$ & $*$ & $*$ \\
\hline IX & 23 & - & - & 28 & - & - & 34 & - & - & 53 & - & - \\
\hline X & 61 & - & - & 47 & - & - & 61 & 1 & 1.6 & 82 & 3 & 3.7 \\
\hline Total & 476 & 8 & $1.7^{\mathrm{a}}$ & 438 & 5 & $1.1^{\mathrm{a}}$ & 353 & 3 & $0.9^{\mathrm{a}}$ & 397 & 6 & $1.5^{\mathrm{a}}$ \\
\hline
\end{tabular}


cows, there was a history of topical treatment of lesions with unspecified antibiotics.

In the chronic stage (stage M4), the lesion sizes ranged from 2.0 to $9.2 \mathrm{~cm}$, consisting of irregular shapes with a convex surface, yellowish-white to blackish-brown hyperkeratotic projections, and painless to touch. In two cows, the lesion extended to the coronary bands, and the commissure of the inter digital space assumed the shape of the letter "W". In an M4 stage, the area of ulceration was reddish, moist, and painful to touch (M4.1).

It was also observed hypertrophy at the edges of the lesions, changes in the corneal tissue of the digits, such as retinal detachment, accumulation of putrid organic matter in the cornea crack formed by the retinal detachment, double sole, and larvae of Cochliomyia spp. (Table 3).

\section{Treatment}

A cure rate of $83.4 \%(5 / 6)$ was obtained after topical treatment with copaiba oil and 75\% (3/4) after topical treatment with salicylic acid paste. It was necessary to have follow-up of the animals until complete skin recovery in an average time of seven weeks (Table 4). After removing the bandage, in seven days, the lesions treated with copaiba oil presented an area of reduced ulcer, as well as in the active lesions and the hyperkeratotic lesions in the chronic stage, covered by whitish crusty material on the lesion and presence of characteristic odor of copaiba oil (Fig.2). A second topical application of copaiba oil with a bandage was carried out on a bovine for seven days. When the bandage was removed, the lesion had a reddish, moist area, painful to the touch, and a putrid odor.

In the treatment with salicylic acid paste, the lesions, when removing the bandage, were covered with a yellowish to whitish crusty material with a characteristic acid odor (Fig.3). In a bovine, the skin adjacent to the lesion was necrotic.

Before topical application of the products and bandages, the manual removal of fly larvae from the lesions was performed with anatomical forceps. By removing the bandage, after seven days, excision of the cracks formed in the corneal tissue, and the double sole was performed with the aid of "rinetas". After removing the bandage until the normal skin recovered, the presence of eggs or fly larvae was not observed.

Table 3. Classification of scores* regarding in bovine digital dermatitis (BDD), clinical signs, lesion location, macroscopic characterization and other changes in the corneal tissue in crossbred dairy cows raised on pasture in the Brazilian Amazon biome

\begin{tabular}{|c|c|c|c|c|c|c|c|c|c|c|}
\hline \multirow{2}{*}{$\begin{array}{l}\text { Stage of } \\
\text { BDD }\end{array}$} & \multirow{2}{*}{ Bovine } & \multirow{2}{*}{ Member** } & \multirow{2}{*}{$\begin{array}{l}\text { Degree of } \\
\text { lameness }\end{array}$} & \multirow{2}{*}{ Anatomical region ${ }^{* * *}$} & \multirow{2}{*}{$\begin{array}{l}\text { Diameter } \\
(\mathrm{cm})\end{array}$} & \multirow{2}{*}{$\mathrm{HH}$} & \multirow{2}{*}{ Fly larvae } & \multicolumn{3}{|c|}{ Alterations in corneal tissue } \\
\hline & & & & & & & & $\mathrm{D}$ & $\mathrm{OM}$ & DS \\
\hline \multirow[t]{5}{*}{ M1 } & 01 & LP & 0 & IC, PL & $1.0 \times 2.0$ & - & - & - & - & - \\
\hline & 02 & LP & 0 & RMQ, PL & $1.6 \times 1.5$ & - & - & - & - & - \\
\hline & 03 & LP & 0 & $\mathrm{CB} / \mathrm{LD}, \mathrm{PL}$ & $1.5 \times 1.7$ & $\mathrm{x}$ & - & - & - & - \\
\hline & 04 & LP & 0 & IC, PL & $1.3 \times 2.0$ & - & - & $\mathrm{x}$ & - & - \\
\hline & 05 & LP & 0 & RMQ, PL & $1.2 \times 2.4$ & $\mathrm{x}$ & - & - & - & - \\
\hline \multirow[t]{8}{*}{ M2 } & 06 & LP & 0 & IC, PL & $2.0 \times 2.0$ & $\mathrm{x}$ & - & - & - & - \\
\hline & 07 & LP & 1 & CB/LD, ET, PL & $3.2 \times 1.5$ & - & $\mathrm{x}$ & $\mathrm{x}$ & $\mathrm{x}$ & - \\
\hline & 08 & $\mathrm{RP}$ & 1 & IC, CB/MD, PL & $2.5 \times 2.5$ & - & - & $\mathrm{x}$ & $\mathrm{x}$ & - \\
\hline & 09 & $\mathrm{RP}$ & 2 & CB/LD, ET, PL & $2.5 \times 4.0$ & - & - & $\mathrm{x}$ & $\mathrm{x}$ & $\mathrm{x}$ \\
\hline & 10 & LP & 2 & CB/LD, ET, PL & $3.7 \times 2.4$ & - & $\mathrm{x}$ & $\mathrm{x}$ & $\mathrm{x}$ & - \\
\hline & 11 & RT & 1 & IC, $\mathrm{C}$ & $4.5 \times 3.6$ & $\mathrm{x}$ & - & $\mathrm{x}$ & - & - \\
\hline & 12 & $\mathrm{RP}$ & 1 & IC, CB/LD e MD, PL & $4.3 \times 5.5$ & $\mathrm{x}$ & $\mathrm{x}$ & $\mathrm{x}$ & - & - \\
\hline & 13 & LP & 2 & IC, CB/LD e MD, ET/MD, PL & $5.0 \times 5.0$ & $\mathrm{x}$ & $\mathrm{x}$ & $\mathrm{x}$ & $\mathrm{x}$ & $\mathrm{x}$ \\
\hline \multirow[t]{5}{*}{ M3 } & 14 & LP & 0 & CB/LD, PL & $0.3 \times 0.4$ & - & - & $\mathrm{x}$ & - & - \\
\hline & 15 & LP & 0 & IC, PL & $0.6 \times 0.9$ & - & - & $\mathrm{x}$ & $\mathrm{x}$ & - \\
\hline & 16 & $\mathrm{RP}$ & 0 & IC, PL & $1.3 \times 2.0$ & - & - & $\mathrm{x}$ & - & - \\
\hline & 17 & LP & 0 & IC, PL & $1.9 \times 4.8$ & - & - & $\mathrm{x}$ & - & - \\
\hline & 18 & LP & 1 & CB/LD, ET, PL & $4.5 \times 3.7$ & $\mathrm{x}$ & - & $\mathrm{x}$ & - & - \\
\hline \multirow[t]{3}{*}{ M4 } & 19 & LP & 0 & CB/LD e MD, PL & $2.8 \times 2.0$ & $\mathrm{x}$ & - & - & - & - \\
\hline & 20 & LP & 1 & IC, CB/LD e MD, PL & $6.4 \times 5.5$ & - & - & $\mathrm{x}$ & $\mathrm{x}$ & - \\
\hline & 21 & LP & 0 & IC, CB/LD e MD, PL & $9.2 \times 7 \times 4$ & $\mathrm{x}$ & - & $\mathrm{x}$ & $\mathrm{x}$ & - \\
\hline M4.1 & 22 & $\mathrm{RT}$ & 2 & CB/LD e MD, PA & $6.0 \times 5.0$ & $\mathrm{x}$ & $\mathrm{x}$ & $\mathrm{x}$ & $\mathrm{x}$ & - \\
\hline
\end{tabular}


Table 4. Topical treatment with salicylic acid paste and crude extract of Copaifera reticulata (Copaiba oil) from stages M1, M2, M4 and M4.1 of bovine digital dermatitis (BDD) in the Brazilian Amazon biome

\begin{tabular}{|c|c|c|c|c|c|}
\hline Topical treatment & Bovine & BDD & Macroscopic characteristic of lesions by removing bandage & $\begin{array}{l}\text { Healing } \\
\text { process } \\
\text { (weeks) }\end{array}$ & Result \\
\hline \multirow{5}{*}{$\begin{array}{l}\text { Salicylic acid paste } \\
\left(\text { Novaderma }^{\circledR}\right)\end{array}$} & 6 & M2 & Surface covered by salicylic acid paste & 8 & Treated \\
\hline & 7 & M2 & Covered by flaky white material & 3 & $-*$ \\
\hline & 8 & M2 & Off-white yellow surface & 10 & $\mathrm{NT} * *$ \\
\hline & 12 & M2 & Yellow surface and skin adjacent to the necrotic lesion & 10 & Treated \\
\hline & 19 & M4 & Brownish-yellow surface & 4 & Treated \\
\hline \multirow{6}{*}{$\begin{array}{l}\text { Crude extract } \\
\text { of Copaifera reticulata }\end{array}$} & 1 & M1 & Covered by flaky white material & 9 & Treated \\
\hline & 10 & M2 & Wet and reddish surface & 8 & Treated \\
\hline & 13 & M2 & Reddish, granular surface and covered with yellowish crusty material & 9 & $\mathrm{NT} * *$ \\
\hline & 20 & M4 & Covered by flaky white material & 10 & Treated \\
\hline & 21 & M4 & Covered by flaky white material & 7 & Treated \\
\hline & 22 & M4.1 & $\begin{array}{l}\text { Circumscribed area with a wet and reddish surface, surrounded by } \\
\text { yellowish material }\end{array}$ & 5 & Treated \\
\hline
\end{tabular}

* Treatment accompanied by only 21 days, as the animal died on the property of unclear cause, ${ }^{* *} \mathrm{NT}=$ non treated.

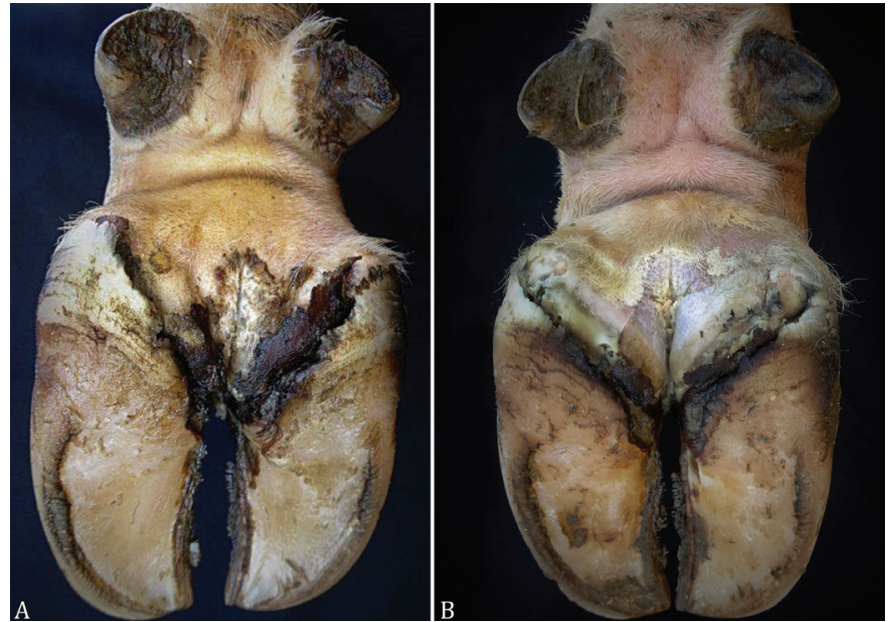

Fig.2. Topical treatment of bovine digital dermatitis with crude extract of Copaifera reticulata (copaiba oil). Bovine 21 referred in Table 4. (A) chronic bovine digital dermatitis (M4) on the day 0; (B) bovine digital dermatitis when the bandage are removed, covered with a whitish to pale yellowish crusty material, day 7 .

\section{DISCUSSION}

The BDD is widespread among cattle herds from the studied properties, with a prevalence of $1.3 \%(22 / 1,664)$. This result was superior to that one observed by Silveira et al. (2009) in 2008 , being performed in the same study region, in which an occurrence of $0.48 \%$ of BDD was observed $(6 / 1,236)$. However, the study conducted by Silveira et al. (2009) paid special attention to claudicating animals. Non-claudicating animals, suffering from initial lesions, as observed in this study, were not detected, which could increase the prevalence rate of BDD in 2008. However, this higher prevalence of BDD in this region may be related to the absence of prophylactic and therapeutic measures for the contagious disease of the foot.

The low prevalence of BDD in cows destined for dairy production, in the Amazon biome, observed in this study

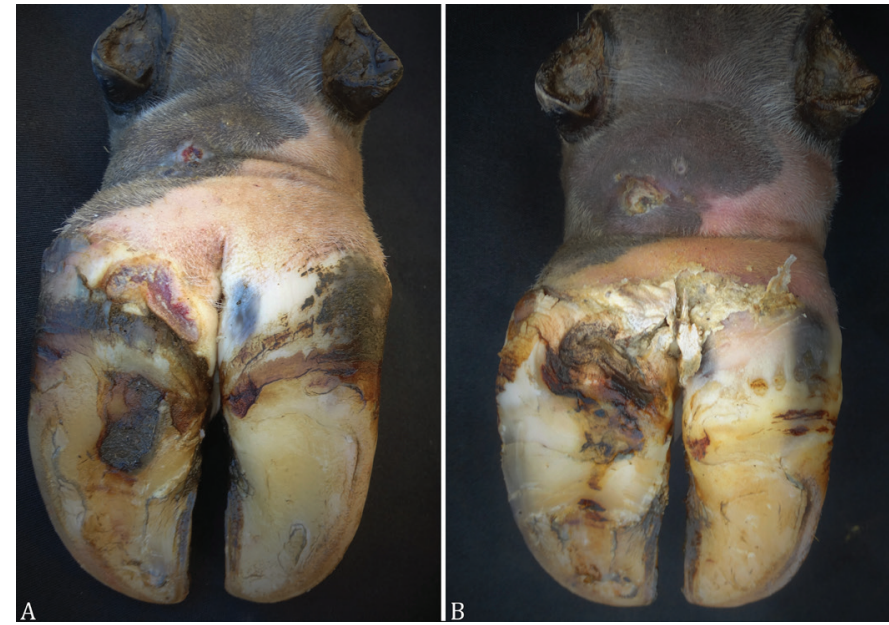

Fig.3. Topical treatment of bovine digital dermatitis with a salicylic acid paste (Novaderma ${ }^{\circledR}$ ). Bovine 7 referred in Table 4. (A) Digital dermatitis in the first stage of ulcer (M2) on the day 0; (B) Bovine digital dermatitis is shown when bandage are removed, without an ulceration area and covered with a whitish to pale yellowish crusty material, day 7 .

and also observed by Machado et al. (2008) and Silveira et al. (2009) was similar to the prevalence of the disease in beef cattle from the same biome, as reported by Silveira et al. (2018), in dairy cows reared under a semi-intensive manner in the Brazilian Cerrado (Leão et al. 2009, Tomasella et al. 2014) and the Atlantic Forest (Souza et al. 2007). However, the prevalence of BDD was at a lowest level, i.e., a minimum of $30 \%$, observed in dairy cows intensively reared and housed in a free-stall system in Brazil (Cruz et al. 2001, Souza et al. 2015), in Canada (Cramer et al. 2008), the Netherlands (Somers et al. 2005), Denmark (Klitgaard et al. 2008), Germany (Nordhoff et al. 2008) and Japan (Yano et al. 2010). These studies emphasize the close relationship between BDD and the type of breeding animals. 
Regarding the extensive breeding system, cattle are kept in extensive pasture areas, areas of lower humidity. The bovine digits are less exposed to feces, and there is less contact between animals, as the concentration of animals per area is low. Breeding conditions opposite to what is observed in stable dairy cows, where digits are exposed continuously to feces and urine, which promote the skin of bovine digits to high humidity, mostly in stables where feces are not scraping frequently, as pointed out by Somers et al. (2005).

The prevalence of BDD in the properties in this study was constant over this time study, with no statistical correlation between the rainfall rate and the occurrence of the disease $(\mathrm{r}=0.02, p=0.38)$, which indicates that the disease can occur at any time of year in the Amazon biome, regardless of whether rains or not (Fig.1). However, a close relationship between a high prevalence of foot infections and poor hygiene conditions is pointed out by Van Metre (2017) or problems with muddy pens by Rodríguez-Lainz et al. (1996). For this reason, we believe that the rainy season may have a significant influence on the occurrence of BDD in the Amazon biome. In this season, the animals remain in pens from two to four hours, i.e., before, during, or after milking with muddy pens, feces, and urine, as reported by Silveira et al. (2009). The influence of the rainy season and the BDD occurrence is shown in Figure 1, where there is an increase in the disease occurrence from December to May.

Relun et al. (2013b) and Krull et al. (2016) observed an average of 140 days ( 5 months) for normal digit skin to present an ulcerated lesion in stable dairy cows. This time of development of the lesions may explain the increase in the prevalence of BDD, although not statistically significant, after the rainy season.

According to Sullivan et al. (2013), lameness is the first clinical sign observed in BDD. In this study, lameness was a clinical sign absent in the initial lesions (M1), in those in the healing stage (M3), and in the chronic (M4) and mild stages, grades form 1 to 2 , in active lesions. For Frankena et al. (2009), the degree of claudication in cattle increases in parallel with the stage or severity of BDD lesions, when deeper and more extensive structures of the skin and or structures of the corneal tissue are reached. Thus, it is necessary to inspect the distal extremities during milking periodically. According to Orsel et al. (2017), the bovine digital space must be inspected during milking, i.e., being an easy practice to be performed and allowed the identification of BDD lesions in the initial stages, for immediate treatment, and monitoring of the herd.

The BDD lesions in the present study occurred preferentially on the skin of the plantar region of the caudal commissure and coronary bands, the preferred location for the formation of the lesions, as was also reported by Read \& Walker (1998) and Cruz et al. (2001). Sogstad et al. (2005) related this preference of lesions to the limbs with more contact with feces and urine. In beef cattle, foot lesions preferentially occur in the pelvic limbs. These are also due to abrasions on the bovine digital skin with the non-castrated cattle, as observed by Silveira et al. (2018). Despite this preference, the thoracic digits and the pelvic digits of dorsal region should also be inspected.

The BDD lesions that formed or reached the cell crown led to the retinal detachment and the formation of a cornea crack. This change, already reported in dairy cows by Cruz et al. (2001) and in beef cattle by Sullivan et al. (2013), is probably related to the interruption or decrease in the supply of nutrients and oxygen to the precursor cells of the corneal tissue, located in the cell crown, due to the inflammatory response triggered. The accumulation of organic matter in these bovine dermatitis accompanied by cracked between the digits, associated with low oxygenation conditions, probably promotes an environment favorable to the colonization of anaerobic bacteria that lead to the destruction of healthy corneal tissue and the occurrence of other changes in the digits such as septic pododermatitis and double sole in cattle. Therefore, BDD can lead to the development of more secondary severe lesions in the digits of cattle. Cruz et al. (2001) also described angular deformations and increased sole thickness as changes secondary to BDD. In treating BDD lesions, it is necessary to remove these secondary changes in the corneal tissue. The development of larvae of flies of the genus Cochliomyia spp. in lesions of BDD, species of Diptera are more common in tropical areas, they can aggravate the lesions and lead cattle to a more severe clinical lameness, as they produce proteolytic enzymes that degrade healthy tissue.

Topical treatment with copaiba oil, protected by bandaging for seven days, proved to have similar therapeutic efficacy when compared to salicylic acid paste. Both showed similar results to the topical treatment with oxytetracycline reported by Manske et al. (2002b). When removing the bandage, both treatments showed improvement in the macroscopic aspects of the lesions, reducing putrid odor and painful to touch. However, among the treatments with copaiba oil, bovine 13 had the area of inflammation of the lesion reduced in the first bandage. However, it presented with large area of ulcers, very painful to touch, and with a putrid odor. The amount of time of contact of the product with the wound was probably not sufficient to treat the injury. In the treatment with salicylic acid paste, it was observed, in a bovine, that the tissue adjacent to the lesion was necrotic. Salicylic acid paste, when used in excess, can react with normal tissue and promote areas of necrosis. Therefore, using this product, an amount of acid sufficient to cover the lesion surface is recommended.

Copaiba oil reduced partial and total ulceration in lesions in the active stage, undid the hyperkeratotic surface, and promoted tissue repair in lesions in the chronic stage. This improvement in the macroscopic characteristic of the lesions, by reducing inflammation, in the keratolytic effect, and in tissue repair, may have resulted from the joint action formula of different compounds present in the copaiba oil described by Cascon \& Gilbert (2000). According to Veiga Júnior et al. (2007), among these compounds, $\beta$-caryophyllene has a potent anti-inflammatory action, and the fractionated diterpenic acids of Copaifera reticulata (ent-kaurenoic acids, kovalenic, (13E)-ent-labda-7,13-dien-15-oic) have high antimicrobial activity, according to Barbosa et al. (2019). Copaiba oil was effective in treating human periodontitis, described by Bardají et al. (2016) and in dogs, by Pieri et al. (2010).

In both treatments, one in each, lesion recurrence was observed. These results pointed out to two possibilities: i) the treatment effect was not significant, since bacteria are found in deep layers of the epidermis, as shown by Zinicola et al. (2015); ii) the treatments were effective, but after a period, the lesions were reinfected, as pointed out by Berry et al. (2010) in lesions of BDD showing clinical improvement at the beginning and then returns to the active stage. In the 
case of ineffective treatments or recurrence of the lesions, it is recommended to perform a second bandage with the same product or alternate the tested topical products.

With the low prevalence of the disease in the region regarding this study and difficulties to reach properties, due to long distances, it was not possible to evaluate both treatments in a larger number of cattle and to compare it with a control group, only being compared with the bandage. According to Manske et al. (2002b), the bandage may promote a longer time of action of the product with the lesion by keeping the bovine digits clean, without contact with mud or feces. Previous studies by Thomsen et al. (2012) pointed out that cleaning the digits periodically, the BDD prevalence can decrease. The results obtained regarding the animals treated in this study were probably related to a joint action formula of the product and the application of the bandage.

\section{CONCLUSIONS}

The BDD is a disease of low prevalence and not seasonal occurrence in crossbred dairy cows raised on pasture in the Brazilian Amazon biome. It is widespread among herds and has macroscopic characteristics similar to the BDD observed in dairy cows from farms housed in a free-stall system.

Copaiba oil has shown positive results regarding the treatment of BDD and may be an alternative to disease control measures in the Brazilian Amazon biome.

Acknowledgments.- The authors thank to the "Coordenação de Nível de Aperfeiçoamento de Pessoal de Nível Superior" (CAPES) for the granting of a doctorate scholarship and also a sandwich doctorate scholarship and to the “Conselho Nacional de Desenvolvimento Científico e Tecnológico" (CNPq), process number 432100/2016-4, for the financial support.

Conflict of interest statement.- There is no conflict of interests.

\section{REFERENCES}

Argáez-Rodríguez F.J., Hird D.W., Anda J.H., Read D.H. \& Rodríguez-Lainz A. 1997. Papillomatous digital dermatitis on a commercial dairy farm in Mexicali, Mexico: Incidence and effect on reproduction and milk production. Prev. Vet. Med. 32(3/4):275-286. <https://dx.doi.org/10.1016/s01675877(97)00031-7><PMid:9443334>

Barbosa A.L.P., Wenzel-Storjohann A., Barbosa J.D., Zidorn C., Peifer C., Tasdemir D. \& Çiçek S.S. 2019. Antimicrobial and cytotoxic effects of Copaifera reticulata oleoresin and its main diterpene acids. J. Ethnopharmacol. 233(1):94-100. <https://dx.doi.org/10.1016/j.jep.2018.11.029>

Bardají D.K.R., Silva J.J.M., Bianchi T.C., Eugênio D.S., Oliveira P.F., Leandro L.F., Rogez H.L.G., Venezianni R.C.S., Ambrosio S.R., Tavares D.C., Bastos J.K. \& Martins C.H.G. 2016. Copaifera reticulata oleoresin: chemical characterization and antibacterial properties against oral pathogens. Anaerobe 40(1):18-27. <https://dx.doi.org/10.1016/j.anaerobe.2016.04.017><PMid:27118478>

Barkema H.W., Westrik J.D., van Keulen K.A.S., Schukken Y.H. \& Brand A. 1994. The effects of lameness on reproductive performance, milk production and culling in Dutch dairy farms. Prev. Vet. Med. 20(4):249-259. <https:// dx.doi.org/10.1016/0167-5877(94)90058-2>

Berry S.L., Read D.H., Famula T.R., Mongini A. \& Döpfer D. 2012. Long-term observations on the dynamics of bovine digital dermatitis lesions on a California dairy after topical treatment with lincomycin HCl. Vet. J. 193(3):654658. <https://dx.doi.org/10.1016/j.tvjl.2012.06.048><PMid:22892182>

Berry S.L., Read D.H., Walker R.L. \& Famula T.R. 2010. Clinical, histologic, and bacteriologic findings in dairy cows with digital dermatitis (footwarts) one month after topical treatment with lincomycin hydrochloride or oxytetracycline hydrochloride. J. Am. Vet. Med. Assoc. 237(5):555-560. <https://dx.doi.org/10.2460/javma.237.5.555> <PMid:20807134>

Blowey R.W. \& Sharp M.W. 1988. Digital dermatitis in dairy cattle. Vet. Rec. 122(21):505-508. <https://dx.doi.org/10.1136/vr.122.21.505> $<$ PMid:3407109>

Bomjardim H.A., Oliveira M.C., Cordeiro M.D., Brito M.F., Fonseca A.H., Oliveira C.M.C., Silva N.S. \& Barbosa J.D. 2020. Detection of Treponema spp. in bovine digital dermatitis in the Amazon biome, Brazil. Pesq. Vet. Bras. 40(6):430437. <https://dx.doi.org/10.1590/1678-5150-pvb-6139>

Brown C.C., Kilgo P.D. \& Jacobsen K.L. 2000. Prevalence of papillomatous digital dermatitis among culled adult cattle in the southeastern United States. Am. J. Vet. Res. 61(8):928-930. <https://dx.doi.org/10.2460/ ajvr.2000.61.928> <PMid:10951985>

Carvalho J.C.T., Cascon V., Possebon L.S., Morimoto M.S.S., Cardoso L.G.V., Kaplan M.A.C. \& Gilbert B. 2005. Topical anti-inflammatory and analgesic activities of Copaifera duckei Dwyer. Phytother. Res. 19(11):946-950. <https://dx.doi.org/10.1002/ptr.1762><PMid:16317651>

Cascon V. \& Gilbert B. 2000. Characterization of the chemical composition of oleoresins of Copaifera guianensis Desf., Copaifera duckei Dwyer and Copaifera multijuga Hayne. Phytochemistry 55(7):773-778. <https://dx.doi.org/10.1016/s0031-9422(00)00284-3><PMid:11190394>

Cheli R. \& Mortellaro C. 1974. La dermatite digitale del bovino. Proceedings of the 8th International Meeting on Diseases Of Cattle, Milan, Italy, p.208-213.

Cramer G., Lissemore K.D., Guard C.L., Lesli K.E. \& Kelton D.F. 2008. Herdand cow-level prevalence of foot lesions in Ontario dairy cattle. J. Dairy Sci. 91(10):3888-3895. <https://dx.doi.org/10.3168/jds.2008-1135> <PMid:18832211>

Cruz C., Driemeier D., Cerva C. \& Corbellini L.G. 2001. Bovine digital dermatitis in southern Brazil. Vet. Rec. 148(18):576-577. <https://dx.doi.org/10.1136/ vr.148.18.576>

Cruz C.E.F., Pescador C.A., Nakajima Y. \& Driemeier D. 2005. Immunopathological investigations on bovine digital epidermitis. Vet. Rec. 157(26):834-840. <https://dx.doi.org/10.1136/vr.157.26.834><PMid:16377788>

Döpfer D., Koopmans A., Meijer F.A., Szakáll I., Schukken Y.H., Klee W., Bosma R.B., Cornelisse J.L., van Asten A.J.A.M. \& ter Huurne A.A.H.M. 1997. Histological and bacteriological evaluation of digital dermatitis in cattle, with special reference to spirochaetes and Campylobacter faecalis. Vet. Rec. 140(24):620-623.<https://dx.doi.org/10.1136/vr.140.24.620> <PMid:9228692>

Evans N.J., Murray R.D. \& Carter S.D. 2016. Bovine digital dermatitis: current concepts from laboratory to farm. Vet. J. 211(1):3-13. <https://dx.doi. org/10.1016/j.tvjl.2015.10.028> <PMid:27061657>

Flower F.C. \& Weary D.M. 2006. Effect of hoof pathologies on subjective assessments of dairy cow gait. J. Dairy Sci. 89(1):139-146. <https://dx.doi. org/10.3168/jds.S0022-0302(06)72077-X><PMid:16357276>

Frankena K., Somers J.G.C.J., Schouten W.G.P., van Stek J.V., Metz J.H.M., Stassen E.N. \& Graat E.A.M. 2009. The effect of digital lesions and floor type on locomotion score in Dutch dairy cows. Prev. Vet. Med. 88(2):150-157. <https://dx.doi.org/10.1016/j.prevetmed.2008.08.004><PMid:18842310>

Holzhauer M., Bartels C.J., van Barneveld M., Vulders C. \& Lam T. 2011. Curative effect of topical treatment of digital dermatitis with a gel containing activated copper and zinc chelate. Vet. Rec. 169(21):555. <https://dx.doi. org/10.1136/vr.d5513><PMid:21957114>

INMET 2018. Instituto Nacional de Meteorologia, Ministério da Agricultura Pecuária e Abastecimento. Available at <http://www.inmet.gov.br> Accessed on Jan. 12, 2018.

Klitgaard K., Boye M., Capion N. \& Jensen T.K. 2008. Evidence of multiple Treponema phylotypes involved in bovine digital dermatitis as shown by $16 \mathrm{~S}$ rRNA gene analysis and fluorescence in situ hybridization. J. Clin. Microbiol.46(9):3012-3020.<https://dx.doi.org/10.1128/JCM.00670-08> <PMid:18562583> 
Krull A.C., Shearer J.K., Gorden P.J., Cooper V.L., Phillips G.J. \& Plummer P.J. 2014. Deep sequencing analysis reveals temporal microbiota changes associated with development of bovine digital dermatitis. Infect. Immun. 82(8):33593373. <https://dx.doi.org/10.1128/IAI.02077-14><PMid:24866801>

Krull A.C., Shearer J.K., Gorden P.J., Scott H.M. \& Plummer P.J. 2016. Natural lesion progression and regression in Holstein dairy cattle over 3 years. J. Dairy Sci. 99(5):3718-3731. <https://dx.doi.org/10.3168/jds.201510535> <PMid:26923049>

Laven R.A. \& Logue D.N. 2006. Treatment strategies for digital dermatitis for the UK. Vet. J.171(1):79-88. <https://dx.doi.org/10.1016/j.tvjl.2004.08.009> <PMid:16427584>

Leão M.A., Silva L.A.F., Jayme V.S., Silva L.M., Moura M.I. \& Barbosa V.T. 2009. Aspectos epidemiológicos da dermatite digital bovina em duas propriedades produtoras de leite do estado de Goiás, Brasil. Ciênc. Anim. Bras. 10(4):1135-1147.

Lodén M., Boström P. \& Kneczke M. 1995. Distribution and keratolytic effect of salicylic acid and urea in human skin. Skin Pharmacol. 8(4):173-178. <https://dx.doi.org/10.1159/000211343><PMid:7488393>

Losinger W.C. 2006. Economic impacts of reduced milk production associated with papillomatous digital dermatitis in dairy cows in the USA. J. Dairy Res. 73(2):244-256. <https://dx.doi.org/10.1017/S0022029906001798> <PMid:16569275>

Machado P.P., Pereira H.M., Santos H.P., Oliveira R.A., Guerra P.C. \& Teixeira W.C. 2008. Prevalência e classificação de afecções podais em fêmeas bovinas destinadas a produção de leite na bacia leiteira do município de Itapecuru Mirim-MA. Revta Bras. Saúde Prod. 9(4):777-786.

Manske T., Hultgren J. \& Bergsten C. 2002a. Prevalence and interrelationships of hoof lesions and lameness in Swedish dairy cows. Prev. Vet. Med. 54(3):247-263. <https://dx.doi.org/10.1016/s0167-5877(02)00018-1> <PMid:12114012>

Manske T., Hultgren J. \& Bergsten C. 2002b. Topical treatment of digital dermatitis associated with severe heel-horn erosion in a Swedish dairy herd. Prev. Vet. Med. 53(3):215-231. <https://dx.doi.org/10.1016/s01675877(01)00268-9> <PMid:11830295>

Molina L.R., Carvalho A.U., Facury Filho E.J., Ferreira P.M. \& Ferreira V.C.P. 1999. Prevalência e classificação das afecções podais em vacas lactantes na bacia leiteira de Belo Horizonte. Arq. Bras. Med. Vet. Zootec. 51(2):149-152. <https://dx.doi.org/10.1590/S0102-09351999000200004>

Monte J., Abreu A.C., Borges A., Simões L.C. \& Simões M. 2014. Antimicrobial activity of selected phytochemicals against Echerichia coli and Staphylococcus aureus and their biofilms. Pathogens 3(2):473-498. <https://dx.doi. org/10.3390/pathogens3020473><PMid:25437810>

Moore D.A., Berry S.L., Truscott M.L. \& Koziy V. 2001. Efficacy of a nonantimicrobial cream administered topically for treatment of digital dermatitis in dairy cattle. J. Am. Vet. Med. Assoc. 219(10):1435-1438. <https://dx.doi.org/10.2460/javma.2001.219.1435><PMid:11724185>

Moreira T.F., Nicolino R.R., Andrade L.S., Facury Filho E.J. \& Carvalho A.U. 2018. Prevalence of lameness and hoof lesions in all year-round grazing cattle in Brazil. Trop. Anim. Health Prod. 50(8):1829-1834.<https://dx.doi org/10.1007/s11250-018-1626-3><PMid:29846882>

Murray R.D., Downham D.Y., Clarkson M.J., Faull W.B., Hughes J.W., Manson F.J., Merritt J.B., Russell W.B., Sutherst J.E. \& Ward W.R. 1996. Epidemiology of lameness in dairy cattle: description and analysis of foot lesions. Vet. Rec. 138(24):586-591. <https://dx.doi.org/10.1136/vr.138.24.586> $<$ PMid:8799985>

Nordhoff M., Moter A., Schrank K. \& Wieler L.H. 2008. High prevalence of treponemes in bovine digital dermatitis- A molecular epidemiology. Vet. Microbiol. 131(3/4):293-300. <https://dx.doi.org/10.1016/j. vetmic.2008.04.019><PMid:18524502>

Orsel K., Plummer P., Shearer J., De Buck J., Carter S.D., Guatteo R. \& Barkema H.W. 2017. Missing pieces of the puzzle to effectively control digital dermatitis. Transbound. Emerg. Dis. 65(supl.1):186-198. <https://dx.doi. org/10.1111/tbed.12729><PMid:29124910>

Pacheco T.A.R.C., Barata L.E.S. \& Duarte M.C.T. 2006. Antimicrobial activity of copaíba (Copaifera spp.) balsams. Revta Bras. Plantas Med. 8(1):123-124.

Pieri F.A., Mussi M.C. \& Moreira M.A.S. 2009. Óleo de copaíba (Copaifera sp.): histórico, extração, aplicações industriais e propriedades medicinais. Revta Bras. Plantas Med. 11(4):465-472. <https://dx.doi.org/10.1590/ S1516-05722009000400016>

Pieri F.A., Mussi M.C., Fiorini J.E. \& Schneedorf J.M. 2010. Efeitos clínicos e microbiológicos do óleo de copaíba (Copaifera officinalis) sobre bactérias formadoras de placa dental em cães. Arq. Bras. Med. Vet. Zootec. 62(3):578585. <https://dx.doi.org/10.1590/S0102-09352010000300012>

Read D.H.\& Walker R.L. 1998. Papillomatous digital dermatitis (footwarts) in California dairy cattle: clinical and gross pathologic findings. J. Vet. Diagn. Invest. 10(1):67-76. <https://dx.doi.org/10.1177/104063879801000112> $<$ PMid:9526863>

Relun A., Lehebel A., Bruggink M., Bareille N. \& Guatteo R. 2013b. Estimation of the relative impact of treatment and herd management practices on prevention of digital dermatitis in French dairy herds. Prev. Vet. Med. 110(3/4):558-562.<https://dx.doi.org/10.1016/j.prevetmed.2012.12.015> $<$ PMid:23369719>

Relun A., Lehebel A., Chesnin A., Guatteo R. \& Bareille N. 2013a. Association between digital dermatitis lesions and test-day milk yield of Holstein cows from 41 French dairy farms. J. Dairy Sci. 96(4):2190-2200. <https://dx.doi. org/10.3168/jds.2012-5934>

Rodríguez-Lainz A., David W., Carpenter T. \& Read D. 1996. Case-control study of papillomatous digital dermatitis in southern California dairy farms. Prev. Vet. Med. 28(2):117-131. <https://dx.doi.org/10.1016/01675877(96)01024-0>

Rodríguez-Lainz A., Melendez-Retamal P., Hird D.W., Read D.H. \& Walker R.L. 1999. Farm- and host-level risk factors for papillomatous digital dermatitis in Chilean dairy cattle. Prev. Vet. Med. 42(2):87-97. <https:// dx.doi.org/10.1016/S0167-5877(99)00067-7><PMid:10551428>

Rondon do Pará, 2018. Clima. Available at <https://pt.climate-data.org/ america-do-sul/brasil/para/rondon-do-para-29546/\#climate-table> Accessed on Oct. 23, 2018.

Santos A.O., Ueda-Nakamura T., Dias Filho B.P., Veiga Júnior V.F., Pinto A.C. \& Nakamura C.V. 2008. Antimicrobial activity of Brazilian copaiba oils obtained from different species of the Copaifera genus. Mem. Inst. Oswaldo Cruz. 103(3):277-281. <https://dx.doi.org/10.1590/S007402762008005000015>

Scholey R.A., Ollier W.E.R., Blowey R.W., Murray R.D. \& Carter S.D. 2010. Determining host genetic susceptibility or resistance to bovine digital dermatitis in cattle. Adv. Anim. Biosci. 1(1):2. <https://dx.doi.org/10.1017/ S2040470010001457>

Schultz N. \& Capion N. 2013. Efficacy of salicylic acid in the treatment of digital dermatitis in dairy cattle. Vet. J. 198(2):518-523. <https://dx.doi. org/10.1016/j.tvjl.2013.09.002><PMid:24268474>

Silva L.A.F., Silva L.M., Romani A.F., Rabelo R.E., Fioravanti M.C.S., Souza T.M. \& Silva C.A. 2001. Características clínicas e epidemiológicos das enfermidades podais em vacas lactantes do município de Orizona-GO. Ciênc. Anim. Bras. 2(2):119-126.

Silveira J.A.S., Albernaz T.T., Oliveira C.M.C., Duarte M.D. \& Barbosa J.D. 2009. Afeções podais em vacas da bacia leiteira de Rondon do Pará. Pesq. Vet. Bras. 29(11):905-909. <https://dx.doi.org/10.1590/S0100-736X2009001100007>

Silveira J.A.S., Silva N.S., Albernaz T.T., Bomjardim H.A., Belo Reis A.S., Oliveira C.M.C., Duarte M.D. \& Barbosa J.D. 2018. Estudo epidemiológico e clínico de afecções podais em bovinos de corte manejados extensivamente no sudeste do Pará. Pesq. Vet. Bras. 38(3):367-373. <https://dx.doi. org/10.1590/1678-5150-pvb-4411> 
Sogstad A.M., Fjeldaas T., Østerås O. \& Plym Forshell K. 2005. Prevalence of claw lesions in Norwegian dairy cattle housed in tie stalls and free stalls. Prev. Vet. Med. 70(3/4):191-209. <https://dx.doi.org/10.1016/j. prevetmed.2005.03.005 > <PMid:16023526>

Somers J.G.C.J., Frankena K., Noordhuizen-Stassen E.N. \& Metz J.H.M. 2005. Risk factors for digital dermatitis in dairy cows kept in cubicle houses in the Netherlands. Prev.Vet. Med. 71(1/2):11-21.<https://dx.doi.org/10.1016/j. prevetmed.2005.05.002 ><PMid:15985303>

Souza A.M., Tulio L.M. \& Gai V.F. 2015. Incidência de lesões podais em bovinos de aptidão leiteira na região oeste do Paraná. Revta Cultiv. Saber 1(1):194-202.

Souza R.C., Carvalho A.U., Ferreira P.M., Facury Filho E.J., Ferreira M.G., Ferreira R.G., Costa C.O. \& Mourthe Neto A. 2007. Prevalência e distribuição de lesões digitais em vacas leiteiras nas regiões de Belo Horizonte e Pedro Leopoldo. Ciênc. Anim. Bras. 8(4):823-831.

Sullivan L.E., Carter S.D., Blowey R., Duncan J.S., Grove-White D. \& Evans N.J. 2013. Digital dermatitis in beef cattle. Vet. Rec. 173(23):582. <https:// dx.doi.org/10.1136/vr.101802><PMid:24106250>

Thomsen P.T., Ersbøll A.K. \& Sørensen J.T. 2012. Short communication: Automatic washing of hooves can help control digital dermatitis in dairy cows. J. Dairy Sci. 95(12):7195-7199. <https://dx.doi.org/10.3168/ jds.2011-5171 ><PMid:23063150>

Tomasella T.E., Negri Filho L.C., Affonso M.Z., Barca Junior F.B., Silva L.C. \& Okano W. 2014. Prevalência e classificação de lesões podais em bovinos leiteiros na região de Belo Horizonte-MG. Revta Bras. Hig. Sanid. Anim. 8(1):115-127. <https://dx.doi.org/10.5935/1981-20140008>
Van Metre D.C. 2017. Pathogenesis and treatment of bovine foot rot. Vet. Clin. N. Am., Food Anim. Pract. 33(2)183-194. <https://dx.doi.org/10.1016/j. cvfa.2017.02.003><PMid:28579042>

Veiga Júnior V.F., Rosas E.C., Carvalho M.V., Henriques M.G.M.O. \& Pinto A.C. 2007. Chemical composition and anti-inflammatory activity of copaiba oils from Copaifera cearensis Huber x Ducke, Copaifera reticulate Ducke and Copaifera multijuga Hayne: a comparative study. J. Ethnopharmacol. 112(2):248-254. <https://dx.doi.org/10.1016/j.jep.2007.03.005> $<$ PMid:17446019>

Wells S.J., Garber L.P. \& Wagner B.A. 1999. Papillomatous digital dermatitis and associated risk factors in US dairy herds. Prev. Vet. Med. 38(1):11-24. <https://dx.doi.org/10.1016/s0167-5877(98)00132-9><PMid:10022049>

Wilson-Welder J.H., Alt D.P \& Nally J.E. 2015. The etiology of digital dermatitis in ruminants: recent perspectives. Vet. Med. (Auckl). 6:155-164. <https://dx.doi.org/10.2147/VMRR.S62072><PMid:30101102>

Yamamoto T., Manabe H., Misawa N., Yamazaki W., Takahashi M. \& Okada K. 2018. Combination effect of allyl isothiocyanate and hoof trimming on bovine digital dermatitis. J. Vet. Med. Sci. 80(7):1080-1085. <https://dx.doi.org/10.1292/jvms.18-0097><PMid:29743458>

Yano T., Moe K.K., Yamazaki K., Ooka T., Hayashi T. \& Misawa N. 2010. Identification of candidate pathogens of papillomatous digital dermatitis in dairy cattle from quantitative $16 \mathrm{~S}$ rRNA clonal analysis. Vet. Microbiol. 143(2/4):352-262.<https://dx.doi.org/10.1016/j.vetmic.2009.12.009> $<$ PMid:20036086>

Zinicola M., Lima F., Lima S., Machado V., Gomez M., Döpfer D., Guard C. \& Bicalho R. 2015. Altered microbiomes in bovine digital dermatitis lesions, and the gut as a pathogen reservoir. Plos One 10(3):e0120504. <https://dx.doi.org/10.1371/journal.pone.0120504><PMid:25781328> 